\title{
Increasing the potential of Cajuput leaf waste as cattle feed through fermentation pretreatment
}

\author{
Ana Widiana ${ }^{1 *}$, Ukit $^{1}$, Prayoga Kusumah ${ }^{1}$, Ayu Wiharyati ${ }^{1}$, Hana Hanifah ${ }^{1}$ \\ ${ }^{1}$ Department of Biology, Faculty of Science and Technology, Universitas Islam Negeri Sunan Gunung Djati \\ Jl. AH. Nasution No. 105A Bandung, West Java, Indonesia. 40614 \\ *Email: anawidiana@uinsgd.ac.id
}

\begin{abstract}
Waste of Cajuput leaves (Melaleuca cajuputi Powell) has the potential to be used as an alternative cattle feed because it has a high nutritional content. The nutritional content of Cajuput leaf waste needs to be improved before being used as an alternative feed. The fermentation process can increase nutrient content in Cajuput leaf waste and increase the organic matter digestibility (OMD), dry matter digestibility (DMD), ammonia $\left(\mathrm{NH}_{3}\right)$ and volatile fatty acid (VFA). This study aimed to determine the improvement of Cajuput leaf waste nutrition with the help of yeast as well as the effect of fermented Cajuput leaf waste along with a mixture of concentrates and field grass on digestibility, $\mathrm{NH}_{3}$ and VFA which were carried out by in vitro test. The results showed the nutritional content of Cajuput leaf waste fermented by yeast of Aspergillus chevalieri had the best value of protein $16.03 \%$, fiber $16.92 \%$ and fat $5.93 \%$. The treatment R4 (50\% Cajuput leaf waste $+25 \%$ concentrate $+25 \%$ field grass) had the best digestibility $(\mathrm{DMD}=46.12 \% ; \mathrm{OMD}=32.08 \%), \mathrm{NH} 3(8.37 \mathrm{mM})$ and VFA $(168.5 \mathrm{mM})$ production.
\end{abstract}

Keywords: Aspergillus chevalieri; dry matter digestibility; Melaleuca cajuputi; nutritional content; organic matter digestibility

Article History: Received 30 January 2021; Received in revised form 14 April 2021; Accepted 30 May 2021; Available online 30 June 2021

How to Cite This Article: Widiana A, Ukit U, Kusumah P, Wiharyati A, Hanifah H.. 2021. Increasing the potential of Cajuput leaf waste as cattle feed through fermentation pretreatment. Biogenesis: Jurnal Ilmiah Biologi. vol 9(1): 81-86. doi: https://doi.org/10.24252/bio.v9i1.21215.

\section{INTRODUCTION}

Organic waste is the alternative feed commonly used in the farms. Organic waste is used because it is cheap, easy to obtain, abundant viability, and has good quality. Feed ingredients consumed by livestock must have good nutritional value for animal health. One alternative feed that can be used as a substitute for conventional forage which is usually reduced its availability, especially in the dry season is Cajuput leaf waste (Widiana et al., 2014). Waste of Cajuput leaves consists of $50 \%$ organic compounds of cellulose, lignin and other organic compounds (Rattanaburi et al., 2013; Dewi, 2016). The main obstacle for the use of organic waste for animal feed is the low nutritional value and digestibility.

The protein content of Cajuput leaf waste is still quite low, which was around $7 \%$ and high fiber content of $21.47 \%$ which could reduce digestibility in animal feed (Widiana $e t$ al., 2014). This data shows that Cajuput leaf waste protein has not met the optimum standard for animal feed. Animal potential feed ingredients can be seen through the parameters of organic matter digestibility
(OMD), dry matter digestibility (DMD), production of ammonia $\left(\mathrm{NH}_{3}\right)$ and volatile fatty acids (VFA) (Noziere et al., 2011; AlArif et al., 2017).

VFA concentration in rumen fluid can be used as an indicator of feed fermentability and is closely related to rumen microbial activity (Zebeli et al., 2012; Maulfair \& Heinrichs, 2013; Hall et al., 2015). Ammonia content in the rumen is positively correlated with microbial protein synthesis, if the concentration of ammonia $\left(\mathrm{NH}_{3}\right)$ and VFA in the rumen increases, microbial protein synthesis will also increase (Syapura et al., 2013; Uddin et al., 2015). As the previous studies, efforts to increase the nutritional content of Cajuput leaf waste can be carried out by several treatments such as physical (enumeration), chemical, and biological (fermentation) (Sitindaon, 2013; Widiana et al., 2019; Noor et al., 2020). Fermentation with the help of microbes (mold) is widely used to help increase the nutritional content/potential of feed ingredients. Some species of mold are known could help in increasing the nutritional content of feed 
ingredients. The protein content increased in the Cajuput leaf waste fermented by mold of Trichoderma viride and Aspergillus niger, but the crude fiber content was still high (Yudiar et al., 2014). Decreasing the fiber content can be provided by adding the other molds. Other research showed that fermentation using the mold of Aspergillus niger and Phanerochaete chrysosporium reduced the levels of crude fiber in rice straw (Supriyatna, 2017). For this reason, research was conducted to increase the potential of Cajuput leaf waste with fermentation pretreatment by Aspergillus chevalieri mold which is an endophytic mold on Cajuput leaf waste.

\section{MATERIALS AND METHODS}

Fermentation. Cajuput leaf waste was obtained from the Jatimunggul Cajuput oil factory, Indramayu. Fermentation of Cajuput leaf waste by Aspergillus chevalieri was carried out at $31^{\circ} \mathrm{C}$ for eight days. Fermentation results were measured by nutritional content with proximate analysis.

In vitro test. According to research conducted (Setiyaningsih et al., 2012), in vitro DMD and OMD analysis (Tilley \& Terry, 1963) can be calculated by the formula:

$\operatorname{DMD}(\%)=$

$\frac{\text { DM sample }(g)-(\text { DM residue }(g)-D M \text { blank }(g))}{D M \text { sample }(g)} \times 100 \%$

OMD $(\%)=$

$\frac{\text { OM sample }(g)-(\text { OM residue }(g)-\text { OM blank }(g))}{\text { OM sample }(g)} \times 100 \%$

Notes:

$\mathrm{DMD}=$ dry matter digestibility $\mathrm{DMD} ; \mathrm{OMD}=$ organic matter digestibility; $\mathrm{DM}=$ dry matter; $\mathrm{OM}=$ organic matter

Production of $\mathrm{NH}_{3}$ analysis (Microdiffusion Conway). Production of $\mathrm{NH}_{3}$ can be calculated by formula (Conway \& O'malley, 1942):

$\mathrm{N}-\mathrm{NH}_{3}=\left(\mathrm{ml} \mathrm{H}_{2} \mathrm{SO}_{4} \times \mathrm{NH}_{2} \mathrm{SO}_{4} \times 1000\right) \mathrm{mM}$

Production of VFA analysis. Production of VFA can be calculated by formula (General Laboratory Procedures, 1966):
Concentration of total VFA $=(b-\mathrm{s}) \times \mathrm{N} \mathrm{HCl} \times 1000 / 5$

Notes:

$\mathrm{b}=$ volume of titran blank; $\mathrm{s}=$ volume of titran sample; $\mathrm{N}=$ liquid normality of $\mathrm{HCl}$

Experimental design. Cajuput leaf waste was mixed with field grass and concentrate to increase its potential as raw material for animal feed. This study used a completely randomized design (CRD) with five treatments and three replications. The ration consisted of four treatment types as follows:

$\mathrm{R} 1=100 \%$ fermented Cajuput leaf waste

$\mathrm{R} 2=50 \%$ fermented Cajuput leaf waste + $50 \%$ concentrate

$\mathrm{R} 3=50 \%$ fermented Cajuput leaf waste + $50 \%$ field grass

$\mathrm{R} 4=50 \%$ fermented Cajuput leaf waste + $25 \%$ field grass $+25 \%$ concentrate

$\mathrm{R} 5=25 \%$ fermented Cajuput leaf waste + $25 \%$ field grass $+50 \%$ concentrate

Data analysis. The OMD, DMD, $\mathrm{NH}_{3}$, and VFA data were subsequently analyzed using the SPSS software ver. 16.0.

\section{RESULTS AND DISCUSSION}

Fermentation results of Cajuput leaf waste. Fermentation using Aspergillus chevalieri produced the largest crude protein $(16.03 \%)$, exceeding the standard for feed by $12 \%$ (Table 1). It was due to the proteolytic mold activity which breaks down proteins into amino acids to increase the dissolved nitrogen. A. chevalieri is a mold that produces many extracellular enzymes, such as pectinase, cellulase, exo- $\beta-1.4$ glucanase, hydrolase, protease, $\alpha$-amylase, glucoamylase, maltase, $\beta$-galactosidase, $\alpha$-glucosidase, glucose oxidase, phosphodiesterase, ribonuclease, 4glycohydrolase, $\beta$-xylosidase, xylanase, and lipase (Ajayi et al., 2014; El-said et al., 2017; Takenaka et al., 2020). Furthermore, high protein content is probably due to an increase in the number of mold cells (Nasseri et al., 2011; Cairns et al., 2019). 
Table 1. The value of nutrient content in fermented Cajuput leaf waste with various single and consortium inoculum treatments.

\begin{tabular}{lll} 
Content & $\begin{array}{l}\text { Raw Cajuput } \\
\text { leaf waste }\end{array}$ & $\begin{array}{l}\text { Fermented Cajuput } \\
\text { leaf waste }\end{array}$ \\
\hline Protein $(\%)$ & 7.04 & 16.03 \\
Fiber $(\%)$ & 21.47 & 16.92 \\
Fat $(\%)$ & 9.06 & 5.93 \\
Ash $(\%)$ & 6.57 & 4.36 \\
\hline
\end{tabular}

Crude fiber consists of cellulose, hemicellulose, lignin, and silica, where the content is influenced by age as well as the species of plants (Jamarun et al., 2020). The fermentation process reduced the value of crude fiber in all treatments. This is in line with SNI standards that the good fiber content used in feed ingredients is $<35 \%$. Crude fat is a lipid contained in feed ingredients and organic compounds that are insoluble in water. However, when dissolved in organic solvents, it becomes a source of energy. Fermentation of Cajuput leaf waste by Aspergillus chevalieri degraded fat to $5.93 \%$ (initial fat value is $9.06 \%$ ). The mold has several hydrolytic enzymes such as lipase which can degrade fat and oils (Gopinath et al., 2013; Chandra et al., 2020).

The ash is an inorganic residual from combusted organic matter, with high content caused by increased mineral components The ash content of the leaf waste fermented by $A$. chevalieri was $4.36 \%$ from $6.57 \%$ (unfermented). This was due to a high mold spore density, hence the available minerals were used as an energy source for growth. Several fungi can utilize inorganic compounds as a source of energy.

Organic matter digestibility, dry matter digestibility, production of $\mathrm{NH}_{3}$ dan VFA. Digestibility is a reflection of nutrients number in feed ingredients which can be utilized by livestock. It can be measured by the difference between the amount of food consumed and excreted in feces, which is considered absorbed in the digestive tract. According to Mackie et al. (2015), the presence of microbial activity in the digestive tract greatly influences digestibility. Meanwhile, bacteria, fungi as well as protozoa are organisms that live in the rumen and appear several weeks after birth. The digestibility of organic matter shows the number of nutrients (fats, carbohydrates, and protein) digested by livestock, while dry matter digestibility indicates levels of food digested by microbes and rumen digestive enzymes. The high percentage of dry digestibility ingredients indicates the higher quality of the feed (Suardin et al., 2014; Hidayat et al., 2019). The digestion value of organic matter (OMD), as well as dry matter digestibility (DMD), are presented in Fig. 1 and Fig. 2.

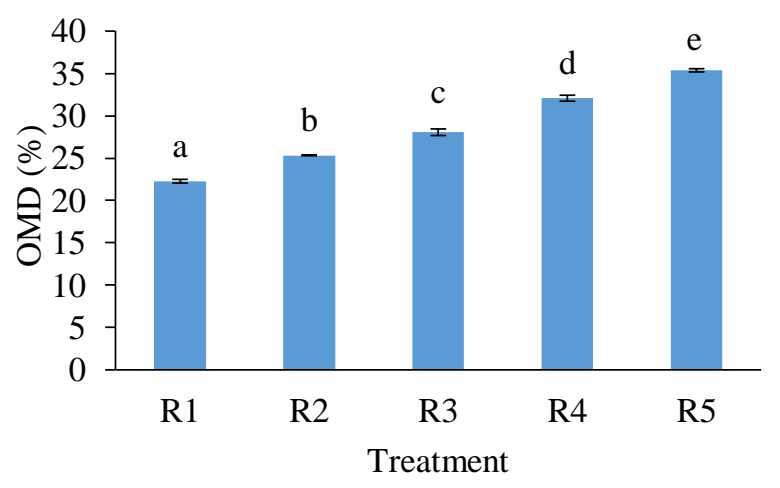

Fig. 1. The digestibility value of organic material in fermented Cajuput leaf waste and its mixture.

Organic digestibility reflects the number of digestible substances, especially nitrogen, carbohydrates, fats, and vitamins. The normal digestibility of organic matter in ruminants is affected by the rumen condition, microbial components as decomposers of organic material in rumen fluid, and certain compounds' content in the feed (Brask et al., 2013; Thirumalesh \& Krishnamoorthy, 2013). Rumen microbes have a very important role in livestock because they can utilize feed nutrients efficiently as an energy source (Das \& Qin, 2012). Furthermore, they ferment forage and fibrous material as basal feed for ruminants. Carbohydrates are broken down by Ruminococcus albus, Ruminococcus flavefaciens, Butyrivibrio fibrisolvens, Megaspaera elsdenii, and Selenomonas ruminantium microbes into three main fermentation products: acetic, propionic, and butyric acids (Flint et al., 2012; Darwin et al., 2018).

The treatment R5 (50\% fermented Cajuput leaf waste and $50 \%$ concentrate) showed the highest digestibility value of organic matter at $35.37 \%$. Also, concentrate affects digestibility because it has a high nutritional value. Hence, 
the increasing crude protein content causes a rise in microbial activity of the rumen and digestion of organic matter. Meanwhile, the percentage of treatment R4 $(50 \%$ Cajuput leaf waste, $25 \%$ field grass, $25 \%$ concentrate) was $32.08 \%$. The factors affecting digestibility include the composition of feed ingredients as well as its comparison, feed treatment, enzyme supplementation, species of livestock, and the feeding level.

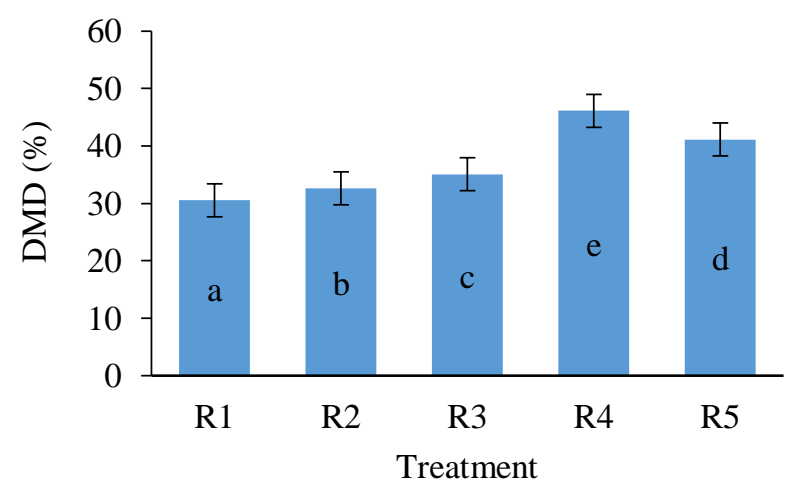

Fig. 2. The dry matter digestibility value in fermented Cajuput leaf waste and its mixture.

The fermented leaf waste in sheep rumen fluid based on in vitro tests of $\mathrm{NH}_{3}$ and VFA production are presented in Fig. 3 and Fig 4. $\mathrm{NH}_{3}$ as the main source of nitrogen is very important for microbial protein synthesis. This shows it is very important for ruminants because microbial protein precursors are ammonia and carbon source compounds (Dewi, 2016).

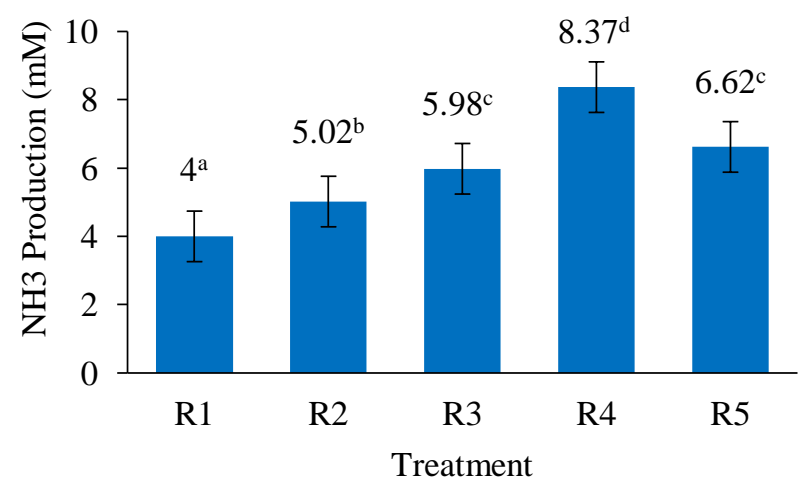

Fig. 3. The $\mathrm{NH}_{3}$ productionin the rumen with the addition of fermented Cajuput leaf waste and its mixture.

The R4 treatment, which had the highest value of $\mathrm{NH}_{3}$ production by $8.37 \mathrm{mM}$, met the production standard of $4-12 \mathrm{mM}$ in the rumen (Sutardi, 1979). Meanwhile, $\mathrm{NH}_{3}$ production is associated with protein degradation by microbes.

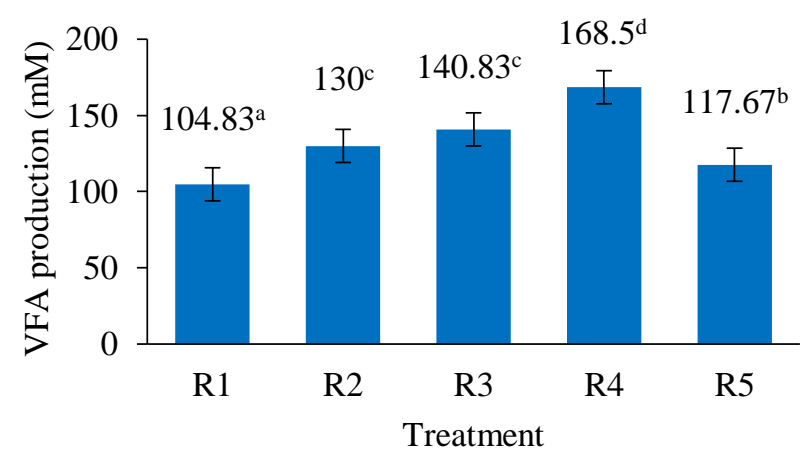

Fig. 4. The VFA production in the rumen with the addition of fermented Cajuput leaf waste and its mixture.

Low protein content in the feed results in low concentrations of rumen $\mathrm{NH}_{3}$ (lower than 50 $\mathrm{mg} / \mathrm{L}$ or $3.57 \mathrm{mM}$ ), which may slow microbial growth. However, when the protein degradation is faster than microbial protein synthesis, $\mathrm{NH}_{3}$ accumulates and exceeds its optimum concentration with ranges between 85-300 $\mathrm{mg} / \mathrm{L}$ or $6-12 \mathrm{mM}$. VFA concentration is influenced by the conditions of the rumen such as microbes, absorption, and fermentability of carbohydrates (Hindratiningrum et al., 2011). The most important functional occupant is bacteria with $10^{9}$ to $10^{10}$ cells in $1 \mathrm{ml}$ of rumen gum and constitutes 5-10\% dry mass of large bowel contents. The VFA concentration results (Fig. 4) are quite high for the survival of ruminant animals as the needed concentration for the livestock optimal growth is $80-160 \mathrm{mM}$. The R4 treatment produced the highest VFA concentration compared to others. This was due to the ration composition consisting of fermented Cajuput leaf waste, field grass, and the concentrate which caused high cellulose content. It has been explained that the VFA composition in the rumen changes with differences in physical form, feed composition, level or frequency of feeding, and processing. In addition, one of the factors influencing its production in the rumen is the amount of fermentability in carbohydrate source feed. High VFA production provides sufficient energy for livestock. It provides $50-70 \%$ of the energy digested by ruminants. Fermentation with Aspergillus chevalieri increases the crude protein content in the leaf waste by $8.19 \%$ and 
reduces crude fiber by $4.55 \%$. This affected its potential as an animal feed ingredient.

This study emphasized the explanation of the QS. Al-Imran verse 191. Humans are given guidance in the form of reason to be used as well as possible in their activities. Among the tasks or activities of the mind mentioned in the verse is meditating on Allah's creation. None of Allah's creation is in vain, everything is correct and worthwhile, even when wasted. Therefore, utilizing waste through micro-organisms treatment is very useful. Further studies need to be carried out with in-vivo techniques to observe the effect on livestock.

\section{CONCLUSION}

The fermentation of Cajuput leaf waste using Aspergillus chevalieri produced animal feed ingredients with nutritional content that met the SNI requirements (protein $16.03 \%$, fiber $16.92 \%$, and fat $5.93 \%$ ), as well as the best digestibility $(\mathrm{DMD}=46.12 \% ; \mathrm{OMD}=32.08 \%)$, $\mathrm{NH}_{3} \quad(8.37 \mathrm{mM})$, and VFA (168.5 mM) production.

\section{ACKNOWLEDGEMENTS}

The authors thank Head of Jatimunggul Cajuput oil factory and Universitas Islam Negeri Sunan Gunung Djati for supporting this study, as well as all participants to make this research came to reality.

\section{REFERENCES}

Ajayi AA, Adejuwon AO, Obasi CK, Olutiola PO, PeterAlbert CF. 2014. Amylase activity in culture filtrate of Aspergillus chevalieri. International Journal of Biological and Chemical Sciences. vol 8(5): 2174 2182. doi: https://doi.org/10.4314/ijbcs.v8i5.21.

Al-Arif MA, Suwanti LT, Estoepangestie AS, Lamid M. 2017. The nutrients contents, dry matter digestibility, organic matter digestibility, total digestible nutrient, and $\mathrm{NH} 3$ rumen production of three kinds of cattle feeding models. KnE Life Sciences. vol 36(6): 338-343. doi: https://doi.org/10.18502/kls.v3i6.1142.

Brask M, Lund P, Hellwing ALF, Poulsen M, Weisbjerg MR. 2013. Enteric methane production, digestibility and rumen fermentation in dairy cows fed different forages with and without rapeseed fat supplementation. Animal Feed Science and Technology. vol 184(1-4): 67-79. doi: https://doi.org/10.1016/j.anifeedsci.2013.06.006.

Cairns TC, Zheng X, Zheng P, Sun J, Meyer V. 2019. Moulding the mould: understanding and reprogramming filamentous fungal growth and morphogenesis for next generation cell factories. Biotechnology for Biofuels. vol 12(1): 1-18. doi: https://doi.org/10.1186/s13068-019-1400-4.

Chandra P, Singh R, Arora PK. 2020. Microbial lipases and their industrial applications: a comprehensive review. Microbial Cell Factories. vol 19(1): 1-42. doi: https://doi.org/10.1186/s12934-020-01428-8.

Darwin D, Barnes A, Cord-Ruwisch R. 2018. In vitro rumen fermentation of soluble and non-soluble polymeric carbohydrates in relation to ruminal acidosis. Annals of Microbiology. vol 68(1): 1-8. doi: https://doi.org/10.1007/s13213-017-1307-x.

Das KC, Qin W. 2012. Isolation and characterization of superior rumen bacteria of cattle (Bos taurus) and potential application in animal feedstuff. Open Journal of Animal Sciences. vol 2(4): 224-228. doi: https://doi.org/10.4236/ojas.2012.24031.

Dewi NS. 2016. Produksi NH3 (amonia) dan VFA (volatile fatty acid) dari limbah daun kayu putih di dalam rumen domba secara in vitro. [Skripsi]. Bandung: Universitas Islam Negeri Sunan Gunung Djati Bandung.

El-said AHM, Hussein MA, Maghraby TA, Meghezel SM. 2017. Screening and optimization of extracellular cellulase and pectinase enzymes produced from post-harvest fungi of apple (Pyrus malus L.) and tomato (Solanum lycopersicum L.). Journal of Environmental Studies [JES]. vol 16: 21-36.

Flint HJ, Scott KP, Duncan SH, Louis P, Forano E. 2012. Microbial degradation of complex carbohydrates in the gut. Gut Microbes. vol 3(4): 289-306. doi: https://dx.doi.org/10.4161\%2Fgmic. 19897.

General Laboratory Procedures. 1966. General Laboratory Procedures. Madison: Department of Diary Science. University of Wisconsin-Madison.

Gopinath SCB, Anbu P, Lakshmipriya T, Hilda A. 2013. Strategies to characterize fungal lipases for applications in medicine and dairy industry. BioMed Research International. vol 2013: 1-11. doi: http://dx.doi.org/10.1155/2013/154549.

Hidayat R, Kamil KA, Suryaningsih L, Utama GL, Balia RL. 2019. Effect of macronutrient needs on digestibility and average daily gain of sheep (Ovisaries var. Padjadjaran, Family Bovidae). International Journal on Advanced Science Engineering Information Technology. vol 9(5): 1618-1623. http://dx.doi.org/10.18517/ijaseit.9.5.9292.

Hindratiningrum N, Bata M, Santosa SA. 2011. Produk fermentasi rumen dan produksi protein mikroba sapi lokal yang diberi pakan jerami amoniasi dan beberapa bahan pakan sumber energi. Agripet. vol 11(2): 29-34. doi: https://doi.org/10.17969/agripet.v11i2.371.

Jamarun N, Pazla R, Arief A, Jayanegara A, Yanti G. 2020. Chemical composition and rumen fermentation profile of mangrove leaves (Avicennia marina) from West Sumatra, Indonesia. 
Biodiversitas Journal of Biological Diversity. vol 21(11): 5230-5236. doi: https://doi.org/10.13057/biodiv/d211126.

Mackie A, Rigby N, Macierzanka A, Bajka B. 2015. Approaches to static digestion models. In: Verhoeckx K. et al. (eds) the impact of food bioactives on health. New York: Springer, Cham. doi: https://doi.org/10.1007/978-3-319-16104-4_3.

Maulfair DD, Heinrichs AJ. 2013. Effects of varying forage particle size and fermentable carbohydrates on feed sorting, ruminal fermentation, and milk and component yields of dairy cows. Journal of Dairy Science. vol 96(5): 3085-3097. doi: https://doi.org/10.3168/jds.2012-6048.

Nasseri AT, Rasoul-Amini S, Morowvat MH, Ghasemi Y. 2011. Single cell protein: production and process. American Journal of Food Technology. vol 6(2): 103-116. doi: https://dx.doi.org/10.3923/ajft.2011.103.116.

Noor AAM, Yusuf SM, Wahab WNAWA, Adam MFIC, Sul'ain MD. 2020. Evaluation on composition, antioxidant and toxicity of Melaleuca cajuputi leaves. Advances in Traditional Medicine. vol 2020: 1-7. doi: https://doi.org/10.1007/s13596020-00479-x.

Noziere P, Glasser F, Sauvant D. 2011. In vivo production and molar percentages of volatile fatty acids in the rumen: a quantitative review by an empirical approach. Animal. vol 5(3): 403-414. doi: https://doi.org/10.1017/S1751731110002016.

Rattanaburi S, Mahabusarakam W, Phongpaichit S, Carroll AR. 2013. A new chromone from the leaves of Melaleuca cajuputi Powell. Natural Product Research. vol 27(3): 221-225. doi: https://doi.org/10.1080/14786419.2012.666750.

Setiyaningsih KD, Christiyanto M, Sutarno S. 2012. Kecernaan bahan kering dan bahan organik secara in vitro hijauan Desmodium cinereum pada berbagai dosis pupuk organik cair dan jarak tanam. Animal Agriculture Journal. vol 1(2): 51-63.

Sitindaon SH. 2013. Inventarisasi potensi bahan pakan ternak ruminansia di Provinsi Riau. Jurnal Peternakan. vol 10(1): 18-23. doi: http://dx.doi.org/10.24014/jupet.v10i1.154.

Suardin S, Sandiah N, Aka R. 2014. Kecernaan bahan kering dan bahan organik campuran rumput mulato (Brachiaria hybrid cv. mulato) dengan jenis legum berbeda menggunakan cairan rumen sapi. Jurnal Ilmu dan Teknologi Peternakan Tropis. vol 1(1): 16-22.

Supriyatna A. 2017. Peningkatan nutrisi jerami padi melalui fermentasi dengan menggunakan konsorsium jamur Phanerochaete chrysosporium dan Aspergillus niger. Jurnal ISTEK. vol 10(2):
$166-181$.

Sutardi T. 1979. Ketahanan protein bahan makanan terhadap degradasi oleh mikroba rumen dan manfaatnya bagi peningkatan produktifitas ternak. Prosiding Seminar Penelitian dan Penunjang Peternakan. Bogor: Lembaga Penelitian dan Pengembangan Pertanian, Republik Indonesia.

Syapura S, Bata M, Pratama WS. 2013. Peningkatan kualitas jerami padi dan pengaruhnya terhadap kecernaan nutrien dan produk fermentasi rumen kerbau dengan feces sebagai sumber inokulum. Agripet. vol 13(2): 59-67. doi: https://doi.org/10.17969/agripet.v13i2.822.

Takenaka S, Nakabayashi R, Ogawa C, Kimura Y, Yokota S, Doi M. 2020. Characterization of surface Aspergillus community involved in traditional fermentation and ripening of katsuobushi. International Journal of Food Microbiology. vol 327: 1-9. doi: https://doi.org/10.1016/j.ijfoodmicro.2020.108654.

Thirumalesh T, Krishnamoorthy U. 2013. Rumen microbial biomass synthesis and its importance in ruminant production. International Journal of Livestock Research. vol 3(2): 5-26.

Tilley JMA, Terry RA. 1963. A two stage technique for the in vitro digestion of forage crops. Grass and Forage Science. vol 18(2): 23-25. doi: https://doi.org/10.1111/j.13652494.1963.tb00335.x.

Uddin J, Khandaker ZH, Khan J, Khan MMH. 2015. Dynamics of microbial protein synthesis in the rumen-a review. Annals of Veterinary and Animal Science. vol 2(5): 116-131.

Widiana A, Taufikurahman T, Limin SH, Hernaman H, Manurung R. 2014. Utilization of solid residue Melaleuca cajuputi Powell leaves as cattle feed. Pakistan Journal of Nutrition. vol 13(10): 554-556.

Widiana A, Hasby RM, Ukit U. 2019. Potency of Cajuput leaf waste as additional feed concentrate. Journal of Physics: Conference Series. vol 1402(3): 1-6. doi: https://doi.org/10.1088/1742-6596/1402/3/033029.

Yudiar RR, Tafsin M, Hanafi ND. 2014. Pemanfaatan Sarbio, Aspergilus niger dan Trichoderma viride pada tongkol jagung terhadap kecernaan serat kasar dan protein kasar pada domba jantan lokal lepas sapih. Jurnal Peternakan Integratif. vol 2(3): 311 320.

Zebeli Q, Metzler-Zebeli BU, Ametaj BN. 2012. Metaanalysis reveals threshold level of rapidly fermentable dietary concentrate that triggers systemic inflammation in cattle. Journal of Dairy Science. vol 95(5): 2662-2672. doi: https://doi.org/10.3168/jds.2011-5080. 